\title{
Viewpoint: Applying riparian buffers to Great Plains rangelands
}

\author{
MICHAEL G. DOSSKEY
}

Author is assistant professor, supported jointly by the USDA Forest Service Rocky Mountain Re'search Station National Agroforestry Center, and the University of Nebraska School of Natural Resource Sciences, Lincoln, Neb. 68583-0814.

\begin{abstract}
Better management of riparian areas has been promoted by public agencies for almost 2 decades. Recently, however, efforts have been intensified because serious conservation concerns remain. To achieve mandated conservation goals for water quality and wildife will require widespread acceptance and application of recommended riparian practices. Success of riparian programs in the Great Plains will require recognition of differences between the interests of public agencies and those of private landowners, and the development of an approach to riparian management that can accommodate both.
\end{abstract}

Key Words: guidelines, management, stream protection, water quality

\section{The Public Interest in Riparian Buffers}

The issue of riparian land management is driven primarily by public interests reflected in 2 federal laws: the Clean Water Act of 1977 (and as amended in 1987) with its mandate to restore and maintain fishable, swimmable waters, and the Endangered Species Act of 1973 that mandates preservation of biological diversity. The goals and requirements of these 2 laws frequently converge on riparian areas where land management directly influences both water quality, and habitat suitability for numerous terrestrial and aquatic species. In response, public policy has focused attention directly on riparian management through programs such as the Riparian-Wetland Initiative for the 1990's (USDI-BLM 1991), the Grazing Lands Conservation Initiative for Private Grazing Lands (USDA-NRCS 1996), and most recently a USDA outreach effort called the National Conservation Buffers Initiative (Max Schnepf, NCBI National Coordinator, pers, comm.).

The term "riparian buffer", as I will use it in this discussion, is a riparian area that is managed differently than other portions of the landscape. In applying riparian buffers, perennial vegetation is managed primarily to provide conservation benefits, such as

\footnotetext{
Manuscript accepted 2 Nov. 1997
}

\section{Resumen}

Las agencias públicas han promovido el mejoramiento del manejo de las areas ribereñas desde hace casi 2 décadas. Sinembargo, recientemente, los esfuerzos se han intensificado debido a que todavía subsisten serias preocupaciones relacionadas con su conservación. Para alcanzar lo estatuido en materia de conservación de vida silvestre y calidad del agua, se requiere de la aceptación y aplicación masiva de las prácticas recomendadas para el manejo de las areas de ribera. El éxito de los programas de ribera en las Planicies requerirádel reconocimiento de las diferencias de intereses entre las agencias públicas y los propietarios privados, y de encontrar propuestas de manejo para las areas de ribera que satisfagan a las dos partes.

filtering runoff and improving habitat. Other common terms, such as streamside management zone, stream protection zone, riparian management area, and riparian buffer strip, vary somewhat within the same riparian buffer concept. A riparian buffer is a management tool that may be used to address goals and requirements of the public interest.

Riparian buffers are applied differently across the U.S. because they are tailored to specific conservation issues that dominate in each region. For example, in the northwest, buffers are employed primarily to restore and protect salmon and trout habitats (Belt, et al. 1992, Elmore and Kauffman 1994). In the arid southwest, buffers improve habitat for more numerous at-risk aquatic and terrestrial species (Krueper 1996). In the east, buffers emphasize reduction of nutrients and sediment that reach streams and estuaries (Welsch 1991, Chesapeake Bay Program 1994). In the Midwest, buffers are used to stabilize stream banks, reduce pollutant runoff, and restore habitat for fish and wildlife in extensively cultivated landscapes (Schultz et al. 1995). This variety of applications is testimony to the flexibility of riparian buffers to address numerous and varied conservation concerns.

Riparian buffers have a role to play on rangelands of the Great Plains, as well. Traditional grazing management has reduced vegetation cover and altered plant communities along many of the region's streams, contributing to erosion and degradation of terrestrial and aquatic habitat (Boldt et al. 1979, Chaney et al. 1990; USEPA 1995). Riparian restoration through special grazing management can reverse these problems in many cases (Kinch 1989, Chaney et al. 1990, 1993, Lauenroth et al. 1994). 
Meeting public goals to produce cleaner water and adequate habitat, however, may require development of some form of riparian buffer along a major extent of the streams in the Great Plains. Degraded riparian areas appear widespread (USEPA 1995). Furthermore, public land and natural resources management agencies have recognized that management of entire watersheds is often necessary to maintain ecological functions that preyent degradation of water quality and endangerment of some species. Accordingly, widespread acceptance of riparian buffers by land managers is necessary to achieve public goals.

\section{Landowner Resistance to Management for Public Goals}

The most outstanding feature that affects management of riparian areas in the Great Plains is the dominance of private ownership (Table 1). Each ranch is an independent business, and ranchers make independent land management decisions. A common thread in the grazing industry is low-input management, where low profit margins rely on limiting investments and optimizing economic and ecological constraints for forage production.

Table 1. Extent and ownership of grazing lands in the United States (adapted from Holechek 1989).

\begin{tabular}{lcc}
\hline \hline Rangeland Type & Area & $\begin{array}{c}\text { Non-federal } \\
\text { ownership }\end{array}$ \\
\hline Western desert and woodlands & 188 & $(\%)$ \\
Great Plains grasslands & 85 & 32 \\
Eastern woodlands and pasture & 197 & 89 \\
\hline
\end{tabular}

The approach used by public agencies to promote riparian buffers among the region's private landowners will be critical to achieve widespread acceptance and application. Special management of riparian areas for water quality and wildlife habitat requires additional investment of money, time, and effort, and there is substantial risk for lost revenue. There is an understandable reluctance among private landowners to change from traditional management schemes that have served production goals for generations to a conservation practice perceived as a risky business option.

The problem for public agencies remains: How to achieve widespread, voluntary application of riparian buffers on private rangelands?

\section{An Approach for Accommodating Both Private and Public Interests}

Both private and public interests can benefit from riparian buffers of healthy, perennial vegetation. A private landowner often gains improved forage production, greater land and livestock protection, better fishing and hunting, and other site-specific benefits (Table 2). If extensive enough, the public can gain improved water quality, healthy populations of at-risk fish and wildlife species, and other watershed-scale benefits. Promoting buffers to landowners for benefits to their ranching operations, rather than public benefit, should facilitate wider acceptance on
Table 2. Potential benefits from riparian buffers at 2 different landscape scales: Installation at a site and installation throughout a watershed.

\begin{tabular}{ll}
\hline \hline Site & Watershed \\
\hline Stabilize eroding banks & $\begin{array}{c}\text { Stabilize stream meanders and } \\
\text { incision }\end{array}$ \\
Filter runoff & $\begin{array}{l}\text { Promote bedload deposition and } \\
\text { raise water table } \\
\text { Even water supply and reduce } \\
\text { peak floods }\end{array}$ \\
Flood damage protection & Cleaner water \\
Debris and shade for fish & Lower water temperature \\
Wildlife cover and food & Wildlife migration corridors \\
Better fishing and game hunting & Productive fisheries and game \\
Wind protection and shade & hahitat \\
for livestock & More extensive habitat for at-risk \\
Produce wood and forage & More diverse community economy \\
& Visually diverse landscape
\end{tabular}

private rangelands and indirectly achieve public goals. Creating this win-win scenario, however, will not be as simple as marketing riparian buffers differently. Tools must be available to design buffers that focus on the needs of landowners. The design of a buffer should show its boundaries and identify the vegetation that it should contain so that the buffer produces an acceptable level of desired benefits. Several management practices may then be used to achieve and maintain this target condition (e.g., Kinch 1989).

Buffers can vary in size, vegetation types, species compositions, and spatial arrangements. For example, grasses, shrubs, and trees have different capabilities to provide site-specific benefits (Table 3). Width of the buffer controls the level of each benefit that can be achieved (Table 4). Each combination of vegetation and width will be more effective at providing certain benefits than others. Management needs will also vary from 1 location to another. Any one landowner will likely have different site problems and management needs from other landowners across the Great Plains region, and buffer designs which satisfy those needs may or may not substantially promote public benefits. An ideal design tool should optimize combinations of landowner and public goals.

A key ingredient, then, to successfully promote riparian buffers to private landowners is a guideline for riparian buffer design that is flexible enough to (i) allow for buffers that are specific to the

Table 3. Relative effectiveness of different vegetation types for providing site-specific benefits (adapted from Dosskey et al. 1997).

\begin{tabular}{|c|c|c|c|}
\hline \multirow[t]{2}{*}{ Benefit } & \multicolumn{3}{|c|}{ Vegetation Type } \\
\hline & Grass & Shrub & Tree \\
\hline Stabilize eroding banks & low & high & high \\
\hline Filter sedinuent & high & low & low \\
\hline Filter dissolved pollutants & medium & low & medium \\
\hline Debris and shade for fish & low & medium & high \\
\hline \multicolumn{4}{|l|}{ Wildlife cover and food } \\
\hline grassland species & high & medium & low \\
\hline forest species & low & medium & high \\
\hline Economic products & medium & low & medium \\
\hline Livestock protection & low & medium & high \\
\hline Flood damage protection & low & medium & high \\
\hline
\end{tabular}


Table 4. Estimated range of minimum buffer widths for providing specific benefits in the Chesapeake Bay (eastern U.S.) region (adapted from Palone and Todd 1997)

\begin{tabular}{lc}
\hline Benefit & Width Range \\
\hline & (m) \\
Wildlife habitat & 10 to $75+$ \\
Flood control & 25 to 60 \\
Sediment filtration & 15 to 45 \\
Nutrient removal & 10 to 40 \\
Stream bank stabilization and aquatic food web & 6 to 15 \\
Water temperature moderation & 5 to 20 \\
\hline
\end{tabular}

needs of each site and rancher, (ii) allow design adjustments, if necessary, to strengthen ecological functions providing critical watershed (public) benefits, and, (iii) produce acceptable results across an ecologically diverse region from Texas to North Dakota.

\section{Guidelines for Designing Riparian Buffers}

There are 3 prominent systems used in the U.S. to design riparian buffers: Proper Functioning Condition developed by the USDI Bureau of Land Management (Prichard et al. 1993); Riparian Forest Buffers developed by the USDA Forest Service and the Chesapeake Bay Program (Welsch 1991; Palone and Todd 1997); and Conservation Practices developed and used by the USDA Natural Resources Conservation Service (USDA-NRCS 1997). Each of these systems has a different degree of flexibility for identifying riparian buffer boundaries and target vegetation, among other characteristics important for delivery to private landowners.

The Proper Functioning Condition system is an ecological assessment system originally designed for application to the Bureau of Land Management's public grazing lands in the west. Its focus is on natural ecosystem health and integrity, and its use emphasizes restoration of aquatic habitat functions. As a design tool, it implicitly considers the entire riparian zone as a special management area. Target vegetation is identified as the natural plant community of the appropriate successional stage that maximizes ecological value, but adjustments can be made toward earlier or later successional stages which have greater potential for other benefits as well, such as forage production. While this provides some flexibility, prescriptions remain focused on whole ecosystems and watershed goals. Using this tool may be complicated, as experts with technical ecology skills may be required to identify the appropriate design, and most of the supporting scientific information is limited to the western U.S.

The Riparian Forest Buffer system is more utilitarian. It originated on the east coast primarily to reduce nonpoint-source water pollution from agricultural lands. This system assumes that a strip of riparian forest provides a basic acceptable level of all ecological functions. Additional ecological, production, and aesthetic benefits are obtained by adjusting other aspects of the design. As a design tool, this system sizes buffers according to site-specific problems and needs, but normally a minimum width for the forest strip portion is established according to the size of stream being protected or its floodplain. Accordingly, the boundaries may not include the entire riparian zone or may include the entire riparian zone plus part of the adjacent uplands, as well. Target vegetation must always include a dominant component of trees (forest), and any management disturbance immediately adjacent to the stream or lake is generally prohibited. An important innovation of this system is the attempt to disassemble the various ecological functions of buffers and associate optimal buffer size and vegetation characteristics to each of them. This effort facilitates design of buffers for specific uses. However, specific recommendations from the current system are clearly intended for eastern conditions (forest), and most of the supporting scientific information pertains to that region as well.

The Natural Resources Conservation Service has developed several conservation practices which can be used to design riparian buffers nationwide. Each practice specifically addresses a subset of conservation problems, such as stream bank stability, erosion control, and wildlife habitat (Table 5). As a design tool, vegetation and size are entirely functions of necessity to solve sitespecific problems. A high degree of flexibility is achieved by combining individual conservation practices, each with its own flexible design features, into 1 riparian prescription. This "combined practices" method, however, compromises simplicity to facilitate administration of financial assistance. Technical assistance from the agency is also necessary to develop an acceptable design. Watershed function and ecosystem health, however, are considered only to the extent that such goals are attained as cumulative site problems are addressed.

Table 5. Conservation Practice Standards of the USDA Natural Resources Conservation Service applicable to riparian buffer design (USDA-NRCS 1997).

\begin{tabular}{lc}
\hline Title & Practice Code \\
\hline Riparian Forest Buffer & 391 \\
Filter Strip & 393 \\
Streambank and Shoreline Protection & 580 \\
Stream Channel Stabilization & 584 \\
\hline
\end{tabular}

Clearly, the ideal design system for marketing buffers to private ranchers in the Great Plains has yet to be developed. Examination of 3 prominent existing systems provides examples of desirable features, although not all equally expressed in any one of them. Each system achieves a different balance between attention to public and private goals. Each system sacrifices some flexibility in order to simplify administration. Each system would require collection of scientific information to produce acceptable and effective buffer designs across the Great Plains.

\section{Conclusion}

I have argued that a landowner goal-oriented approach to riparian management coupled with a flexible buffer design system, would improve prospects for achicving public conservation goals on rangelands in the Great Plains. My reasoning is based on recognition of a difference between public and private goals, and that buffers can be designed to accommodate both and be promoted within the business constraints of ranching operations. Direct attention to site-specific problems of interest to private land owners would appeal directly to the broadest group of land managers in this region, and provide a more compelling reason for voluntary change from traditional management schemes. 
Some compromises will likely be necessary to make this approach work. Private landowners may have to accept some limitations to design flexibility, to facilitate technical and financial assistance by public agencies. Such assistance will be important to reduce financial risk to landowners and to ensure that riparian buffer designs incorporate characteristics favorable to critical wildlife and water quality (Wiebe et al. 1997). Public agencies must accept that this approach may not achieve maximum public benefits, since it optimizes attainment of both public and private goals. Such compromises, however, should be viewed as a cost of achieving broad, voluntary acceptance and widespread application by private landowners in the Great Plains.

\section{Literature Cited}

Belt, G.H., J. O'Laughlin, and T. Merrill. 1992. Design of Forest Riparian Buffer Strips for the Protection of Water Quality: Analysis of Scientific Literature. Univ. of Idaho, Idaho Forest, Wildl. and Range Policy Anal. Group Rep. No. 8, Moscow, Ida.

Boldt, C.E., D.W. Uresk, and K.E. Severson. 1979. Riparian woodland enclaves in the prairie draws of the northern high plains: A look at problems, a search for solutions. p. 31-32. In: Riparian and Wetland Habitats of the Great Plains. Great Plains Agr. Counc. Pub. No. 91., USDA Forest Serv., Rocky Mtn. For. \& Range Exp. Sta., Ft. Collins, Colo.

Chaney, E., W. Elmore, and W.S. Platts. 1990. Livestock Grazing on Western Riparian Areas. U.S. Environ. Protect. Agency and Northwest Res. Info. Ctr., Inc., Eagle, Ida.

Chaney, E., W. Elmore, and W.S. Platts. 1993. Managing Change: Livestock Grazing on Westem Riparian Arcas. U.S. Environ. Protect. Agency and Northwest Res. Info. Ctr., Inc., Eagle, Ida.

Chesapeake Bay Program. 1994. Achieving the Chesapeake Bay Nutrient Guals: A Synthesis of Tributary Strategies for the Bay's Ten Watersheds. U.S. Environ. Protect. Agency, Annapolis, Md.

Dosskey, M.G., R.C. Schultz, and T.M. Isenhart. 1997. How To Design a Riparian Buffer for Agricultural Land. Agroforestry Notes 4 (Jan.):1-4. Nat. Agroforestry Ctr., Lincoln, Neb.

Elmore, W. and B. Kauffman. 1994. Riparian and watershed systems: degradation and restoration. p. 212-231. In: M.Vavre, W.A. Laycock and R.D. Pieper (eds.) Ecological Implications of Livestock Herbivory in the West. Soc. for Range Manage., Denver, Colo.

Holechek, J.L., R.D. Pieper, and C.H. Herbel. 1989. Range Management: Principles and Practices. Prentice Hall, Englewood Cliffs, N. J.

Kinch, G. 1989. Riparian Area Management: Grazing Management in Riparian Areas. USDI Bur. of Land Manage., TR 1737-4, Denver, Colo.

Krueper, D.J. 1996. Effects of livestock management on Southwestern riparian ecosystems. p. 281-301. In: D.W. Shaw and D.M. Finch (eds.) Desired Future Conditions for Southwestern Riparian Ecosystems: Bringing Interests and Concerns Together. USDA Forest Serv., Gen. Tech. Rep. RM-272, Ft. Collins, Colo.

Lauenroth, W.K., D.G. Milchunas, J.L. Dodd, R.H. Hart, R.K. Heitschmidt, and L.R. Rittenhouse. 1994. Effects of grazing on ecosystems of the Great Plains. p. 69-100. In: M.Vavre, W.A. Laycock and R.D. Pieper (eds.) Ecological Implications of Livestock Herbivory in the West. Soc. for Range Manage., Denver, Colo.

Palone, R.S. and A.H. Todd (eds.). 1997. Chesapeake Bay Riparian Handbook: A Guide for Establishing and Maintaining Riparian Forest Buffers. USDA Forest Serv., NA-TP-02-97, Radnor, Penn.

Prichard, D., H. Barrett, J. Cagney, R. Clark, J. Fogg, K. Gebhardt, P. Hansen, B. Mitchell, and D. Tippy. 1993. Riparian Area Management: Process for Assessing Proper Functioning Condition. USDI BLM, TR 1737-9, Rev. 1995., Denver, Colo.

Schultz, R.C., T.M. Isenhart, and J.P. Colletti. 1995. Riparian Buffer Systems in Crop and Rangelands. p. 13-27. In: W.J. Rietveld (tech. coord.) Agroforestry and Sustainable Systems: Symposium
Proceedings. USDA Forest Serv., Gen. Tech. Rep. RM-261, Ft. Collins, Colo.

USDI Bureau of Land Management. 1991. Riparian-Wetland Initiative for the 1990's. USDI, BLM/WO/GI-91/001+4340, Wash. D.C.

USDA Natural Resources Conservation Service. 1996. Non-Federal Grazing Lands in the United States. Program Aid 1552w. Wash. D.C.

USDA Natural Resources Conservation Service. 1997. National Handbook of Conservation Practices. Wash. D.C.

U.S. Environmental Protection Agency. 1995. Agriculture and Environment. Fact Sheets for Colorado, Kansas, Nebraska, North Dakota, South Dakota, and Texas. Office of Policy, Planning and Evaluation, Wash. D.C.

Welsch, D.J. 1991. Riparian Forest Buffers: Function and Design for Protection and Enhancement of Water Resources. USDA Forest Serv., NA-PR-07-91, Radnor. Penn.

Wiebe, K.D., A. Tegene, and B. Kuhn. 1997. Finding common ground on public and private land. J. Soil and Water. Conserv. 52:162-165. 